\title{
Perception on the Usage of Mobile Assisted Language Learning (MALL) in English as a Second Language (ESL) Learning among Vocational College Students
}

\author{
Wan Ummu Aiman Wan Azli, Parilah Mohd Shah, Maslawati Mohamad \\ Faculty of Education, National University of Malaysia (UKM), Bangi, Malaysia \\ Email: wanummuaiman@gmail.com
}

How to cite this paper: Azli, W. U. A. W., Shah, P. M., \& Mohamad, M. (2018). Perception on the Usage of Mobile Assisted Language Learning (MALL) in English as a Second Language (ESL) Learning among Vocational College Students. Creative Education, 9, 84-98.

https://doi.org/10.4236/ce.2018.91008

Received: December 30, 2017

Accepted: January 28, 2018

Published: January 31, 2018

Copyright $\odot 2018$ by authors and Scientific Research Publishing Inc. This work is licensed under the Creative Commons Attribution International License (CC BY 4.0).

http://creativecommons.org/licenses/by/4.0/

(c) (i) Open Access

\begin{abstract}
Mobile phones are viewed as significant aids to English language learning. Numerous studies have been conducted in different contexts on mobile assisted language learning (MALL) that indicate the benefits of mobile devices for English language learning. Nevertheless, few studies on MALL had been conducted on among vocational college students in Malaysia. Therefore, this study was aimed to investigate the perception on the usage of MALL in English as a Second Language (ESL) among private vocational college students. Data were collected from a survey questionnaire adapted from Technology Acceptance Model (TAM). The results show the respondents have positive perception on the usage of MALL. Majority of the respondents showed overall agreement on both constructs perceived usefulness (PU) and perceived ease of use (PEOU) of MALL. They believed the usage of MALL will enhance the teaching and learning process. This evidence of acceptance has implication for educators and curriculum designers to exploit the mobile phone for autonomous and interactive ESL learning beyond the classroom context. It is hoped that MALL will be used as one of the teaching aids that could assist educators to teach English as a Second Language (ESL) more effectively.
\end{abstract}

\section{Keywords}

Mobile Phone, Mobile Assisted Language Learning (MALL), Vocational

College Students, Technology Acceptance, Modal (TAM), Perceived

Usefulness (PU), Perceived Ease of Use (PEoU)

\section{Introduction}

Among the portable technological tools, mobile phones are the most commonly 
used devices for learning (Pęcherzewska \& Knots, 2007). This statement made based on the findings derived from their study on analysis of mobile learning projects funded by the European Union from 2001 to 2007. It was found that mobile phones have become popular among users, and frequently used more than any other devices.

The preference of mobile phones in educational setting is due to its mobility and accessibility as being mentioned by Tayebinik \& Puteh (2012). According to Kukulska-Hulme \& Shield (2008), mobile learning is a type of learning that takes place with the help of mobile devices. They defined the term "mobile learning" as being available "anywhere, anytime". Therefore, the key term, "mobile learning", is defined as the learning tools that constantly available anywhere and at any time.

The application of Mobile Assisted Language Learning (MALL) currently increases with the use of a handheld mobile device especially in the Malaysian context. In 2008, the Malaysian Communication and Multimedia Commission (MCMC) has conducted a survey. The findings indicate that the main users of mobile phone were those between 20 to 49 years (Hussin et al., 2012), and the number is rising, along with improved ease of access to and sharing of information. In addition, it is a portable technological device which is always switched on and a useful mini-computer that fit in a student's pocket (Prensky, 2005).

Many studies have been conducted in different contexts on the applications of mobile phones in L2 teaching and learning. Most findings highlight the positive results of mobile devices for language learning environments (Stockwell, 2008; Steel, 2012). One of the positive results is the learning process is more interactive (Shield \& Kukulska, 2008). They claimed that mobile learning is recognized as an interactive type of technology-based learning. By interacting and collaborating via the mobile device, the learners are actively involved in interesting and useful learning activities.

Most of the studies in Malaysia were carried out at tertiary level. However, limited studies have been conducted on the use of Mobile Assisted Language Learning (MALL) in vocational colleges. Therefore, this study was aimed is to investigate the perception on the usage of Mobile Assisted Language Learning (MALL) in English as a Second Language (ESL) learning among private vocational college students in Selangor. Thus, the following research questions driving this study are as follow: 1) What are the vocational college students' perception on the perceived usefulness (PU) of mobile assisted language learning (MALL)? 2) What are the vocational college students' perceptions on the perceived ease of use (PEoU) of mobile assisted language learning (MALL)?

It is hoped that the findings of this study could provide some insights to the linguists and educators on the information on language planning and policy related to MALL. Moreover, by having better understanding on the usage of MALL, students would have increased opportunities for learning English outside the formal setting. It will also provide teachers with some knowledge on stu- 
dents' needs and preferences in which this will help to promote better learning process. Lastly, the study also becomes a useful launching platform for further studies in the area of the use of technology or devices in education field.

\section{Literature Review}

\subsection{The Technology Acceptance Model (TAM)}

This model introduced by Davis $(1986,1989)$ that was derived from the Theory of Reasoned Action (TRA) (Fishbein \& Ajzen, 1975). According to Davis, it offers a powerful explanation for user acceptance and usage behaviour of information technology. The TAM was designed to aid in the prediction of technology acceptance based on the constructs of perceived usefulness, perceived ease of use, attitudes, and behavioural intention.

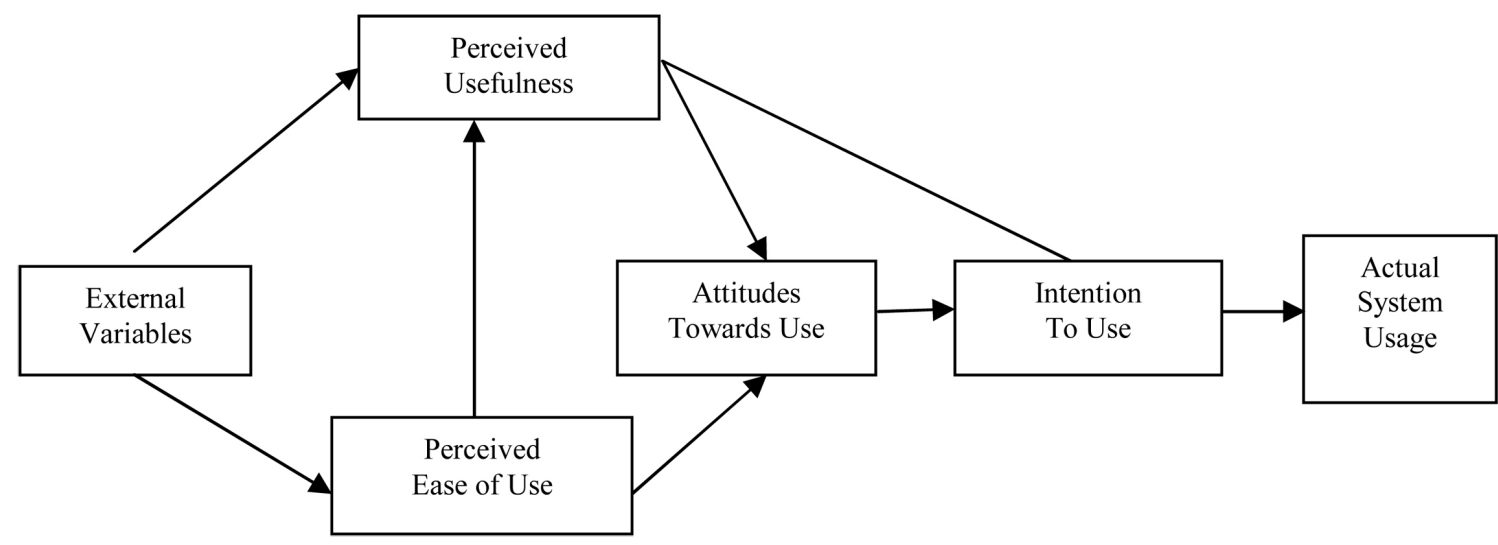

Based on TAM model, an individual's behavioural intention to adopt a system is determined by two beliefs, perceived usefulness and perceived ease of use. Davis (1989: p. 320), further defined perceived usefulness as "the degree to which an individual believes that using a particular system would enhance his or her productivity" while perceived ease of use is defined as "the degree an individual believes that using a particular system would be free of effort". According to both definitions, perceived ease of use has a direct effect on both perceived usefulness and technology usage (Davis, 1989; Adams et al., 1992).

Davis (1986) stated that the user would put less effort with a tool which is easy to use, thus they will be able to spare efforts to accomplish other tasks. Perceived ease of use could help improving one's performance. In this study, perceived usefulness and perceived ease of use were used to analyze students' perceptions on the usage of MALL in English as a Second Language Learning (ESL).

\subsection{Past Studies Adopting TAM Model}

Chen \& Jang (2013) in their study aimed to investigate user acceptance of technology in an informal environment. In this study, they distributed tablets to university students studying EFL. The participants were instructed to keep a record on their usage of these tablets for language study. Then, they also need to 
complete a survey based on the TAM adapted version of questionnaire. The results showed that students believed tablets as to be easy to use, effective and that they were satisfied with the device for informal language study.

Many studies indicate that MALL brings many advantages on both partiesthe educators and users. The portability of mobile device gives more flexibility to learner to carry out collaborative activities inside classroom. Zhu, Guo, \& Hu (2012) claimed that when using mobile phones, the seating of the students does not have to be arranged in a fixed manner, as it does when interacting with a computer. Learners could move, interact, and participate actively in classroom activities while carrying their mobile devices.

Zhu et al. (2012) further stated that the usage of MALL accelerate teaching and learning process. It is time consuming for the students when copying down lecture notes on the whiteboard. The usage of mobile phone reduces the time for copying notes whereby students could just take the photos of the notes written by their teacher using mobile's camera. They were very glad as it eased their note taking.

However, there are also disadvantages on the usage of MALL depending on the objective/s of the lesson. Beatty (2013) mentioned that the usage of MALL would not help the students to practice their copying and writing skills however MALL could be the easiest and economical way for the students to get information by taking the photos only.

Furthermore, Itayem (2014) in his study examined students' behavioral intentions towards using the iPad in their language learning courses through utilizing the Technology Acceptance Model of Davis (1989). There were 25 undergraduate student participants completed an iPad-usage questionnaire to measure their perceived usefulness (PU), perceived ease of use (PEOU), attitude towards usage (ATU), and behavioral intention to use the iPad (BIU) in their integrated language learning courses (reading, writing, listening, and speaking). The results showed students' perceived usefulness and perceived ease of use of the iPad positively predicted the students' attitude towards using the iPad and their behavioral intention to use it in their language classes and other contexts.

\subsection{Mobile Assisted Language Learning (MALL)}

Besides that, Kukulska-Hulme \& Shield (2007) comprehensively reviewed MALL-related research, emphasizing on speaking and listening skills. Their research was on the types of mobile devices namely mobile phones, tablet PCs, and MP3 players. It was found that MALL differs from computer-assisted language learning in term of its personal use, portable devices which allow the new ways a leaning, easy access and interaction across different contexts of use. MALL is focused more on learner centered learning compared than traditional learning process.

Moreover, Levy \& Kennedy (2005) cited a study by Dias (2002) conducted a survey to investigate whether students practice English using their cell phones, if 
they trained to do so. The findings of the survey found that $57.9 \%$ of female students responded positively and $47.4 \%$ of male students replied in a favorable way. Thus in general, it proved that mobile-assisted language learning have gained a wide acceptance as studies result a positive attitude among students and teacher.

On the other hand, even though mobile devices have been proven to be successful for educational purposes, their deployment demands from researcher to investigate students attitudes, whether they "can, will, and want to use them for education" (Pollara, 2011: p. 28). Pollara (2011) proposed that there are different opinions on mobile devices. Some consider them as personal tool, others perceive them as helping students to cheat on exams, but others acknowledge their pedagogical affordances as a valuable tool for delivering lesson in learning context.

In addition, Lawrence (2015) conducted a study to examine learner receptiveness towards using smartphones to enhance EFL learning at a Korean university in various manners and contexts, exploring predictors of learner attitude towards mobile devices. 159 L2 learners of college English program participated in this study. The results indicated that half of the participants demonstrated positivity towards integration, while others were ambivalent, with only a small proportion actively against integration.

Thus, this study was conducted to identify vocational college students' perception on the usage of MALL. By knowing students' perception it will help teachers to employ new and advanced teaching tools in learning process regardless of the setting either in the classroom or outside.

\section{Research Methodology}

\subsection{Research Setting and Respondents}

This study adopted quantitative approach. The purpose of this study was to investigate perception on the usage of Mobile Assisted Language Learning (MALL) in English as a Second Language (ESL) learning among vocational college students. 100 students of KRU Academy vocational college were involved. The respondents took Diploma in Technology of Visual Effects and Diploma in Technology of 2D Animation. The main criterion for the sampling is that the participants must have almost same level of English proficiency. Thus, the selection is based on their English final examination grade.

In this study, convenience sampling was used to obtain the respondents. Lavrakas (2008) explained that it is a type of non-probability sampling in which people are sampled simply because they are "convenient" sources of data for researchers. All the respondents involved were due to their willingness to be respondents of this study.

\subsection{Research Instruments}

A survey questionnaire employed in this study was adapted from Davis (1993) in 
his study "User acceptance of information technology: system characteristics, user perceptions and behavioral impacts.” The questionnaire contains 26 items and was divided into three sections.

Section A consists of 6 items which seek information on students' background. The background information questionnaire aimed to understand the respondents' demographic information. Next, Section B contains 10 items to draw out information regarding perceived usefulness (PU) about mobile assisted learning. Lastly, Section C contains ten items aimed at extracting students' perceived ease of use (PEoU) about mobile assisted learning.

The questionnaire was designed using 6 Likert scale for Section B and Section C. Both sections indicated 6 "strongly agree", 5 "agree", 4 "slightly agree", 3 "slightly disagree", 2 "disagree", and 1 "strongly disagree". Before the questionnaire was employed in this study, a pilot study was carried out to ensure the validity and the reliability of the instrument.

\subsection{Data Collection and Analysis}

In order to collect data, the questionnaire was distributed to the respondents. The researcher gave detailed explanation about the questionnaire. Next, the respondents were given one hour to answer the questionnaire. The researcher was around to assist the respondents while they were answering the questionnaire.

All the quantitative data collected from the questionnaire was analyzed by SPSS 20 descriptive statistics. The data were presented in percentage and frequency form. Next, data from Section A and Section B were initially analyzed and converted to mean scores in order to obtain perception on the usage of (MALL) in English as a Second Language (ESL) learning among vocational college students. Finally, the responses in the questionnaires were examined and computed by SPSS descriptive analysis.

\section{Findings}

\subsection{Demographic Background of Respondents}

The demographic background of the respondents such as course of study and grade for English final examination are important independent variables in this study. The demographic backgrounds of the respondents were discussed in detailed below.

Table 1 demonstrates the distribution of respondents by their course of study. In this study, majority of the respondents (55\%) were taking Diploma of Technology in 2D Animation. In addition, (45\%) of them were taking Diploma of Technology in Visual Effects.

Table 2 indicates the distribution of respondents by English final examination grade. The data revealed that (78\%) of the respondents obtained A- to A for their English subject. Besides that, there were (20\%) of the respondents who obtained $\mathrm{B}-$ to $\mathrm{B}+$. Only a minority of the respondents $(2.0 \%)$ obtained $\mathrm{C}-$ to $\mathrm{C}+$ for their English subject. Clearly, the respondents who were involved in this 
Table 1. Frequency distribution of respondents' course of study.

\begin{tabular}{cccc}
\hline \multicolumn{2}{c}{ Variables } & Frequency & Percent \\
\hline \multirow{3}{*}{ Course } & VFX & 45 & 45.0 \\
& 2D & 55 & 55.0 \\
& Total & 100 & 100.0 \\
\hline
\end{tabular}

Table 2. Frequency distribution of respondents' English final examination grade.

\begin{tabular}{rccc}
\hline \multicolumn{2}{c}{ Variables } & Frequency & Percent \\
\hline \multirow{3}{*}{ English } & A- to A & 78 & 78.0 \\
Grade & B- to B+ & 20 & 20.0 \\
& C- to C+ & 2 & 2.0 \\
& Total & 100 & 100.0 \\
\hline
\end{tabular}

study possess good English proficiency level.

\subsection{Perceived Usefulness (PU)}

In this study, the respondents' perceptions on the perceived usefulness (PU) of mobile assisted language learning (MALL) for 10 items were analyzed. Their perceptions on (PU) were obtained using five point Likert-scale with 1 "strongly disagree", 2 "disagree", 3 "slightly disagree", 4 "slightly agree", 5 "agree", and 6 "strongly agree".

Table 3 shows frequency distribution of perceived usefulness (PU) items. Firstly for Item 1, majority of the respondents (45\%) agreed that using MALL improves the quality of task. However, for only (1\%) slightly disagreed that "using MALL improves the quality of task". Moreover, a high proportion of respondent $(60 \%)$ responded for Item 2 that they agreed "using MALL gives greater control over task" and only one student was slightly disagreed that "using MALL gives greater control over task".

On the other hand, other response for Item 3 shows that (47\%) agreed "MALL enables them to accomplish task quickly". Additionally, for Item 4, (42\%) respondents' slightly agreed that "MALL supports critical aspects of their task".

Besides that, for item 5 (43\%) of the respondents agreed that the using MALL increases their productivity' and for Item 6 (47\%) of them shared the same point of view that using MALL improves their task performances.

In addition for Item 7, the majority (48\%) agreed that "MALL allows them to accomplish more tasks" as well as for Item 8 "enhances their effectiveness on the task completion". Furthermore, for Item 9 (43\%) agreed that the using MALL in language made them easier to complete their task. Overall, for Item 10 half of the respondents (50\%) strongly agreed that MALL is useful in their task.

Table 4 displays the mean scores for each aspect of the perceived usefulness (PU). It showed that the respondents perceived using mobile phones as useful for learning English, particularly when they do their task or assignment. The highest mean score $(M=5.29)$ was generally they find MALL useful in their task. 
Table 3. Frequency distribution of perceived usefulness (PU).

\begin{tabular}{|c|c|c|c|c|c|c|c|c|}
\hline & Items & STD & $\mathrm{D}$ & SD & SA & A & STA & Total \\
\hline 1. & $\begin{array}{l}\text { Using MALL improves the } \\
\text { quality of task I do }\end{array}$ & $\begin{array}{l}0 \% \\
(0)\end{array}$ & $\begin{array}{c}0 \\
(0)\end{array}$ & $\begin{array}{l}1 \% \\
(1)\end{array}$ & $\begin{array}{l}19 \% \\
(19)\end{array}$ & $\begin{array}{l}45 \% \\
(45)\end{array}$ & $\begin{array}{l}35 \% \\
(35)\end{array}$ & $\begin{array}{l}100 \% \\
(100)\end{array}$ \\
\hline 2. & $\begin{array}{l}\text { Using MALL gives me } \\
\text { greater control over my task }\end{array}$ & $\begin{array}{l}0 \% \\
(0)\end{array}$ & $\begin{array}{l}0 \% \\
(0)\end{array}$ & $\begin{array}{l}1 \% \\
(1)\end{array}$ & $\begin{array}{l}24 \% \\
(24)\end{array}$ & $\begin{array}{l}60 \% \\
(60)\end{array}$ & $\begin{array}{l}15 \% \\
(15)\end{array}$ & $\begin{array}{l}100 \% \\
(100)\end{array}$ \\
\hline 3. & $\begin{array}{l}\text { MALL enables me to } \\
\text { accomplish task more quickly }\end{array}$ & $\begin{array}{l}0 \% \\
(0)\end{array}$ & $\begin{array}{l}0 \% \\
(0)\end{array}$ & $\begin{array}{l}1 \% \\
(1)\end{array}$ & $\begin{array}{l}14 \% \\
(14)\end{array}$ & $\begin{array}{l}47 \% \\
(47)\end{array}$ & $\begin{array}{l}38 \% \\
(38)\end{array}$ & $\begin{array}{l}100 \% \\
(100)\end{array}$ \\
\hline 4. & $\begin{array}{l}\text { MALL supports critical } \\
\text { aspects of my task }\end{array}$ & $\begin{array}{l}0 \% \\
(0)\end{array}$ & $\begin{array}{l}0 \% \\
(0)\end{array}$ & $\begin{array}{l}3 \% \\
(3)\end{array}$ & $\begin{array}{l}42 \% \\
(42)\end{array}$ & $\begin{array}{l}38 \% \\
(38)\end{array}$ & $\begin{array}{l}17 \% \\
(17)\end{array}$ & $\begin{array}{l}100 \% \\
(100)\end{array}$ \\
\hline 5. & Using MALL increases my productivity & $\begin{array}{l}1 \% \\
(1)\end{array}$ & $\begin{array}{l}0 \% \\
(0)\end{array}$ & $\begin{array}{l}5 \% \\
(5)\end{array}$ & $\begin{array}{l}31 \% \\
(31)\end{array}$ & $\begin{array}{l}43 \% \\
(43)\end{array}$ & $\begin{array}{l}20 \% \\
(20)\end{array}$ & $\begin{array}{l}100 \% \\
(100)\end{array}$ \\
\hline 6. & $\begin{array}{l}\text { Using MALL improves } \\
\text { my task performance }\end{array}$ & $\begin{array}{l}0 \% \\
(0)\end{array}$ & $\begin{array}{l}0 \% \\
(0)\end{array}$ & $\begin{array}{l}4 \% \\
(4)\end{array}$ & $\begin{array}{l}24 \% \\
(24)\end{array}$ & $\begin{array}{l}47 \% \\
(47)\end{array}$ & $\begin{array}{l}25 \% \\
(25)\end{array}$ & $\begin{array}{l}100 \% \\
(100)\end{array}$ \\
\hline 7. & $\begin{array}{l}\text { Using MALL allow me to } \\
\text { accomplish more task than } \\
\text { would otherwise be possible }\end{array}$ & $\begin{array}{l}0 \% \\
(0)\end{array}$ & $\begin{array}{l}0 \% \\
(0)\end{array}$ & $\begin{array}{l}4 \% \\
(4)\end{array}$ & $\begin{array}{l}25 \% \\
(25)\end{array}$ & $\begin{array}{l}48 \% \\
(48)\end{array}$ & $\begin{array}{l}23 \% \\
(23)\end{array}$ & $\begin{array}{l}100 \% \\
(100)\end{array}$ \\
\hline 8. & $\begin{array}{l}\text { Using MALL enhances my } \\
\text { effectiveness on the task completion }\end{array}$ & $\begin{array}{l}0 \% \\
(0)\end{array}$ & $\begin{array}{l}0 \% \\
(0)\end{array}$ & $\begin{array}{l}4 \% \\
(4)\end{array}$ & $\begin{array}{l}29 \% \\
(29)\end{array}$ & $\begin{array}{l}48 \% \\
(48)\end{array}$ & $\begin{array}{l}19 \% \\
(19)\end{array}$ & $\begin{array}{l}100 \% \\
(100)\end{array}$ \\
\hline 9 & $\begin{array}{l}\text { Using MALL makes it } \\
\text { easier to do my task }\end{array}$ & $\begin{array}{l}0 \% \\
(0)\end{array}$ & $\begin{array}{l}0 \% \\
(0)\end{array}$ & $\begin{array}{l}2 \% \\
(2)\end{array}$ & $\begin{array}{l}18 \% \\
(18)\end{array}$ & $\begin{array}{l}43 \% \\
(43)\end{array}$ & $\begin{array}{l}37 \% \\
(37)\end{array}$ & $\begin{array}{l}100 \% \\
(100)\end{array}$ \\
\hline 10. & Overall, I find MALL useful in my task & $\begin{array}{l}0 \% \\
(0)\end{array}$ & $\begin{array}{l}0 \% \\
(0)\end{array}$ & $\begin{array}{l}4 \% \\
(4)\end{array}$ & $\begin{array}{l}13 \% \\
(13)\end{array}$ & $\begin{array}{l}33 \% \\
(33)\end{array}$ & $\begin{array}{l}50 \% \\
(33)\end{array}$ & $\begin{array}{l}100 \% \\
(100)\end{array}$ \\
\hline
\end{tabular}

Note: STD: Strongly Disagree; D: Disagree; SD: Slightly Disagree; SA: Slightly Agree; A: Agree; STA: Strongly Agree.

Table 4. Descriptive statistical analysis of perceived usefulness (PU).

\begin{tabular}{cccc}
\hline & Mean & Std. Deviation & N \\
\hline Using MALL improves the quality of task I do & 5.14 & 0.75 & 100 \\
Using MALL gives me greater control over my task & 4.89 & 0.65 & 100 \\
MALL enables me to accomplish task more quickly & 5.22 & 0.72 & 100 \\
MALL supports critical aspects of my task & 4.69 & 0.78 & 100 \\
Using MALL increases my productivity & 4.75 & 0.90 & 100 \\
Using MALL improves my task performance & 4.93 & 0.81 & 100 \\
Using MALL allow me to accomplish more task & 4.90 & 0.79 & 100 \\
than would otherwise be possible & & & \\
Using MALL enhances my effectiveness & 4.82 & 0.78 & 100 \\
$\quad$ on the tasks completion & 5.15 & 0.78 & 100 \\
Using MALL makes it easier to do my task & 5.29 & 0.84 & 100 \\
$\quad$ Overall, I find MALL useful in my tasks & & & \\
\hline
\end{tabular}

Next, the second highest score was $(M=5.22)$ which stated MALL enables them to accomplish task more quickly.

Additionally, the respondents were strongly agreed with the other two items with mean scores $(M=5.15)$ and $(M=5.14)$. They believed that using MALL 
makes it easier to do task as well as improves the quality of task they do. Meanwhile, the respondents reported that they were slightly agreed with the other items on perceived usefulness. The mean score $(M=4.93)$ which stated using MALL improves task performance, followed by accomplishing more tasks than otherwise would be possible $(M=4.90)$, and gives greater control over their tasks $(M=4.89)$. Besides that, almost similar results were derived for the following three items. The mean score $(M=4.82)$ for enhancing their effectiveness on the task completion, $(\mathrm{M}=4.75)$ for increasing their productivity and finally for supporting critical aspects of their task $(M=4.69)$.

Based on the findings, it was clearly shown that the respondents have a positive perception on the usefulness of MALL for them. They agreed that the "integration of MALL brings a lot of benefits for them while doing their tasks".

\subsection{Perceived Ease of Use (PEoU)}

For this section, the respondents' perceptions on the perceived ease of use usefulness (PEoU) of mobile assisted language learning (MALL) for 10 items were analyzed. Their perceptions on (PEoU) were obtained using five point Likert-scale with 1 "strongly disagree", 2 "disagree", 3 "slightly disagree", 4 "slightly agree", 5 "agree", and 6 "strongly agree".

The statements for items number 12,14, 16, 18 and 20 were positive while items number 11,13,15, 17 and 19 were negative.

Table 5 demonstrates the frequency distribution of perceived ease of use (PEoU) which shows different frequency of each item. Firstly, it is clear from the table that there is an overall disagreement with Item 11. Most of the, respondents disagreed (37\%) and strongly disagreed (24\%) that MALL is cumbersome to use. However, (11\%) of the respondents slightly agreed and (1\%) agreed with the statement about MALL is cumbersome to use. As for the results of Item 12, a large number of respondents (49\%) agreed that learning to operate MALL is easy for them. On the other hand, the rest (3\%) of the respondents slightly disagreed with this item.

Concerning Item 13, (34\%) of the respondents disagreed that interacting via the MALL is often frustrating. A slightly significant number of respondents who stated they slightly agreed (13\%) or agree (3\%) with this statement. Furthermore, for Item 14, a high proportion of the respondents (43\%) agreed that it is easy to get MALL do what they want it to do. Only (9\%) of them slightly disagreed with this statement.

The respondents' report show mixed responses on the Item 15 on either "MALL is rigid or inflexible to interact with". (33\%) of the respondents disagreed and (24\%) slightly disagreed with this statement. By contrast, (19\%) slightly agreed and (11\%) agreed that MALL is hard to handle. Other than that, for Item 16, (48\%) of the respondents agreed that they easily remember how to perform the task using MALL. However, (17\%) of the respondents chose slightly disagree. 
Table 5. Frequency distribution of perceived ease of use (PEoU).

\begin{tabular}{|c|c|c|c|c|c|c|c|c|}
\hline & Items & STD & D & $\mathrm{SD}$ & $\mathrm{SA}$ & A & STA & Total \\
\hline 11. & $\begin{array}{l}\text { I find the MALL } \\
\text { cumbersome to use }\end{array}$ & $\begin{array}{l}24 \% \\
(24)\end{array}$ & $\begin{array}{l}37 \% \\
(37)\end{array}$ & $\begin{array}{l}27 \% \\
(27)\end{array}$ & $\begin{array}{l}11 \% \\
(11)\end{array}$ & $\begin{array}{l}1 \% \\
(1)\end{array}$ & $\begin{array}{l}0 \% \\
(0)\end{array}$ & $\begin{array}{l}100 \% \\
(100)\end{array}$ \\
\hline 12. & $\begin{array}{l}\text { Learning to operate the } \\
\text { MALL is easy for me }\end{array}$ & $\begin{array}{l}0 \% \\
(0)\end{array}$ & $\begin{array}{l}0 \% \\
(0)\end{array}$ & $\begin{array}{l}3 \% \\
(3)\end{array}$ & $\begin{array}{l}20 \% \\
(20)\end{array}$ & $\begin{array}{l}49 \% \\
(49)\end{array}$ & $\begin{array}{l}28 \% \\
(28)\end{array}$ & $\begin{array}{l}100 \% \\
(100)\end{array}$ \\
\hline 13. & $\begin{array}{l}\text { Interacting via the } \\
\text { MALL is often } \\
\text { frustrating }\end{array}$ & $\begin{array}{l}23 \% \\
(23)\end{array}$ & $\begin{array}{l}34 \% \\
(34)\end{array}$ & $\begin{array}{l}27 \% \\
(27)\end{array}$ & $\begin{array}{l}13 \% \\
(13)\end{array}$ & $\begin{array}{l}3 \% \\
(3)\end{array}$ & $\begin{array}{l}0 \% \\
(0)\end{array}$ & $\begin{array}{l}100 \% \\
(100)\end{array}$ \\
\hline 14. & $\begin{array}{l}\text { I find it is easy to get } \\
\text { the MALL to do what I } \\
\text { want it to do }\end{array}$ & $\begin{array}{l}0 \% \\
(0)\end{array}$ & $\begin{array}{l}0 \% \\
(0)\end{array}$ & $\begin{array}{l}9 \% \\
(9)\end{array}$ & $\begin{array}{l}28 \% \\
(28)\end{array}$ & $\begin{array}{l}43 \% \\
(43)\end{array}$ & $\begin{array}{l}20 \% \\
(20)\end{array}$ & $\begin{array}{l}100 \% \\
(100)\end{array}$ \\
\hline 15. & $\begin{array}{l}\text { MALL is rigid and } \\
\text { inflexible to } \\
\text { interact with }\end{array}$ & $\begin{array}{l}10 \% \\
(10)\end{array}$ & $\begin{array}{l}33 \% \\
(33)\end{array}$ & $\begin{array}{l}24 \% \\
(24)\end{array}$ & $\begin{array}{l}19 \% \\
(19)\end{array}$ & $\begin{array}{l}11 \% \\
(11)\end{array}$ & $\begin{array}{l}3 \% \\
(3)\end{array}$ & $\begin{array}{l}100 \% \\
(100)\end{array}$ \\
\hline 16. & $\begin{array}{l}\text { It is easy for me to } \\
\text { remember how to } \\
\text { perform my task } \\
\text { using the MALL }\end{array}$ & $\begin{array}{l}0 \% \\
(0)\end{array}$ & $\begin{array}{l}0 \% \\
(0)\end{array}$ & $\begin{array}{l}17 \% \\
(17)\end{array}$ & $\begin{array}{l}27 \% \\
(27)\end{array}$ & $\begin{array}{l}48 \% \\
(48)\end{array}$ & $\begin{array}{l}18 \% \\
(18)\end{array}$ & $\begin{array}{l}100 \% \\
(100)\end{array}$ \\
\hline 17. & $\begin{array}{l}\text { Interacting via the } \\
\text { MALL requires a lot } \\
\text { of mental effort }\end{array}$ & $\begin{array}{l}7 \% \\
(7)\end{array}$ & $\begin{array}{l}42 \% \\
(42)\end{array}$ & $\begin{array}{l}32 \% \\
(32)\end{array}$ & $\begin{array}{l}14 \% \\
(14)\end{array}$ & $\begin{array}{l}4 \% \\
(4)\end{array}$ & $\begin{array}{l}1 \% \\
(1)\end{array}$ & $\begin{array}{l}100 \% \\
(100)\end{array}$ \\
\hline 18. & $\begin{array}{l}\text { My interaction via the } \\
\text { MALL is clear and } \\
\text { understandable }\end{array}$ & $\begin{array}{l}0 \% \\
(0)\end{array}$ & $\begin{array}{l}0 \% \\
(0)\end{array}$ & $\begin{array}{l}9 \% \\
(9)\end{array}$ & $\begin{array}{l}29 \% \\
(29)\end{array}$ & $\begin{array}{l}45 \% \\
(45)\end{array}$ & $\begin{array}{l}17 \% \\
(17)\end{array}$ & $\begin{array}{l}100 \% \\
(100)\end{array}$ \\
\hline 19. & $\begin{array}{l}\text { I find it takes a lot of } \\
\text { effort to become skillful } \\
\text { at using MALL }\end{array}$ & $\begin{array}{l}10 \% \\
(10)\end{array}$ & $\begin{array}{l}24 \% \\
(24)\end{array}$ & $\begin{array}{l}33 \% \\
(33)\end{array}$ & $\begin{array}{l}19 \% \\
(19)\end{array}$ & $\begin{array}{l}14 \% \\
(14)\end{array}$ & $\begin{array}{l}0 \% \\
(0)\end{array}$ & $\begin{array}{l}100 \% \\
(100)\end{array}$ \\
\hline 20. & $\begin{array}{l}\text { Overall, I find the } \\
\text { MALL is easy to use }\end{array}$ & $\begin{array}{l}0 \% \\
(0)\end{array}$ & $\begin{array}{l}0 \% \\
(0)\end{array}$ & $\begin{array}{l}4 \% \\
(4)\end{array}$ & $\begin{array}{l}16 \% \\
(16)\end{array}$ & $\begin{array}{l}33 \% \\
(33)\end{array}$ & $\begin{array}{l}47 \% \\
(47)\end{array}$ & $\begin{array}{l}100 \% \\
(100)\end{array}$ \\
\hline
\end{tabular}

Note. STD: Strongly Disagree; D: Disagree; SD: Slightly Disagree; SA: Slightly Agree; A: Agree; STA: Strongly Agree.

Moreover, for Item 17 a high percentage (42\%) disagreed that interacting with MALL requires a lot of mental efforts. Likewise, (32\%) slightly disagreed (7\%) while strongly disagreed with this statement. On the other side, (14\%) of the respondents were "slightly agree". In addition, the findings for Item 18 show that most of the respondents (45\%) agreed that their interaction via MALL is clear and understandable yet a significant number (9\%) indicate that they were slightly disagreed.

As far Item 19 is concerned, (33\%) chose slightly disagree that it takes a lot of effort to become skillful at using MALL. Similarly, (24\%) disagreed with this statement. However, the rest (19\%) of them slightly agreed. Finally, for Item 20 (47\%) of the respondents strongly agreed that in overall they find MALL is easy to use. Then, the other (33\%) respondents also show their agreement on this statement. 
As can be seen from Table 6, the results show the mean scores for each aspect of this construct, perceived ease of use (PEoU). In general, the possible assumption that could be derived based on different scores of mean was two types of statement for each item. Some items have positive statement whereas the rest of the statements have negative statements.

The highest mean score obtained was $(M=5.23)$ which the respondents stated that they agreed that in overall MALL is easy to use. Similarly, the respondents choose to agree with the statement that learning to operate MALL is easy for them, $(M=5.02)$.

Besides that, the respondents show agreement with the other three items. The mean score for the item, it is easy for them to remember how to perform their task using MALL $(\mathrm{M}=4.77)$, followed by the item that stated they find it is easy for MALL to do what they want it to do $(M=4.74)$ and lastly they claimed their interaction via MALL is clear and understandable $(M=4.70)$.

In addition, the respondents' response either they find it takes a lot of effort to become skillful at using MALL was at the medium level with $(\mathrm{M}=3.03)$. They chose that they were slightly disagreed with this statement. It means that they are not sure how hard it is to become skillful at using MALL.

On the other hand, there were low levels of mean scores for the other four items. All these items are negative statement about MALL. Firstly, for the item that MALL is rigid and inflexible to interact with $(M=2.97)$ which means quite some number of respondents disagreed with this statement. Secondly, the respondents reported on "interacting via MALL requires lots of mental efforts with $(\mathrm{M}=2.69)^{\prime}$. Almost similar result was obtained with slightly significant number of respondents disagreed. Likewise, the same result for "interacting via the

Table 6. Descriptive statistical analysis of Perceived Ease of Use (PEoU).

\begin{tabular}{|c|c|c|c|}
\hline & Mean & Std. Deviation & $\mathbf{N}$ \\
\hline I find the MALL cumbersome to use & 2.28 & 0.99 & 100 \\
\hline Learning to operate the MALL is easy for me & 5.02 & 0.78 & 100 \\
\hline Interacting via the MALL is often frustrating & 2.39 & 1.07 & 100 \\
\hline $\begin{array}{l}\text { I find it is easy to get MALL to do } \\
\text { what I want it to do }\end{array}$ & 4.74 & 0.88 & 100 \\
\hline MALL is rigid and inflexible to interact with & 2.97 & 1.28 & 100 \\
\hline $\begin{array}{l}\text { It is easy for me to remember how to } \\
\text { perform my task using the MALL }\end{array}$ & 4.77 & 0.83 & 100 \\
\hline $\begin{array}{c}\text { Interacting via the MALL requires } \\
\text { a lot of mental effort }\end{array}$ & 2.69 & 1.00 & 100 \\
\hline $\begin{array}{l}\text { My interaction via the MALL } \\
\text { is clear and understandable }\end{array}$ & 4.70 & 0.86 & 100 \\
\hline $\begin{array}{l}\text { I find it takes a lot of effort to } \\
\text { become skillful at using MALL }\end{array}$ & 3.03 & 1.17 & 100 \\
\hline Overall, I find the MALL is easy to use & 5.23 & 0.86 & 100 \\
\hline
\end{tabular}


MALL is often frustrating" $(M=2.39)$ followed by they "find MALL is cumbersome to use $(M=2.28)$ ". Thus, the conclusion that could be derived is that regardless of difficulty to use MALL the respondents do not share the same opinion regarding this aspect.

\subsection{Discussion}

The findings of this study reveal that most of the respondents had positive perceptions toward the usage of mobile assisted language learning (MALL) in regard to both constructs perceived usefulness (PU) and perceived ease of use (PEoU). Likewise, they show a general agreement on the potential of MALL as a convincing approach for English as Second Language English (ESL). These results are also parallel with Itayem's (2014) findings that the students' perceived usefulness and perceived ease of use are significant when establishing the students' attitude towards the iPad.

Besides that, based on the findings it can be concluded that the respondents have positive perceptions on the usefulness of MALL for them. Majority of the respondents stated that they agreed with all the statement items of perceived usefulness with the highest percentage for each item. Therefore, the findings explain that the respondents believed using MALL brings a lot of benefits for them while doing their task. More than that, Lawrence (2015) in his study had similar result with this study; almost half of student participants demonstrated a positive perception towards the integration of smartphones for language learning. Therefore, the positive perception of these students provides a positive environment for the integration of MALL among educators for delivering English programs at colleges in Korea.

At the meantime, the findings for perceived ease of use items on the questionnaire also showed that the respondents have positive perceptions on the usage of MALL regardless either the statements were positive or negative. However, a small number of respondents showed their disagreement on certain items. This variety of responses given by the respondents could be because of different level of skills in using MALL. According to Koole (2009), the learners' skill and their prior knowledge and experience with mobile devices for learning affected their perception towards the usage of MALL.

The most important finding in this study is was in overall a high proportion of the respondents strongly agreed with the statement about the easiness in using MALL. This is an indication of the positive perception of the role of MALL in enhancing learners' English. In addition, Traxler (2009) stated that mobile devices or smart phones are the promising devices future of language learning since these devices are changing the language learning process become more genuine, personalized as well as situated. Moreover, Kukulska-Hulme (2013) proposed that the new century call for greater learner autonomy with the flexible use of new learning tool like mobile phone has changed the traditional way of all language skills will be learned in future. Thus, it is recommended the usage of 
MALL as new teaching aids in classroom.

\section{Conclusion}

It could be concluded that the results of this study show that the respondents which are the English learners as a second language strongly believed the role of MALL in enhancing the teaching and learning process. The integration of MALL in language classroom gave the opportunity for the learners to access various useful materials, try different activities in English, as well as to communicate and interact with their friends and lecturers using English.

There are some implications of this study. The integration of MALL helps teachers and students to have more conducive learning environment and complement the traditional style of teaching. There are plenty applications in mobile phone that could make learning process much more interesting and easily attract students' attention as well as having better understanding on the lesson.

Besides that, the other implication of positive perceptions among respondents of vocational college for curriculum designers and teachers is the need for rethinking and redesigning the learning materials to integrate mobile language learning opportunities for students to explore. The usage of MALL will allow students to take part in learning activities regardless of time and place. Therefore, the suggestion should be taken in consideration by the teachers or educators for further action in order to make learning process become easier and interesting.

Moreover, (Surina \& Kamaruzaman, 2009) stated that teacher should consider the usage of mobile phones in improving their teaching as the conventional method is no longer effective for younger generation whom being exposed with gadget since they were small. The mobile phone is an appropriate tool that allows communication and interaction between teachers and students happens outside of the classroom. It enables teachers and students to discuss about lesson without face to face learning process.

On the other side, there are some limitations of this study. It was a small scale study that represents only 100 students of a vocational college in Selangor. Therefore, it is suggested that a bigger sample should be included for future study in order for the results to be generalized to bigger population.

\section{References}

Adams, D. A., Nelson, R. R., \& Todd, P. A. (1992). Perceived Usefulness, Ease of Use, and Usage of Information Technology: A Replication. MIS Quarterly, 16, 227-247. https://doi.org/10.2307/249577

Beatty, K. (2013). Teaching \& Researching: Computer-Assisted Language Learning. Less Commonly Taught Languages. Routledge CARLA. Center for Advanced Research on Language Acquisition (CARLA). http://carla.umn.edu/lctl/index.html

Chen, H. Y., \& Jang, S. J. (2013). Exploring the Reasons for Using Electric Books and Technologic Pedagogical and Content Knowledge of Taiwanese Elementary Mathematics and Science Teachers. Turkish Online Journal of Educational Technology-TOJET, $12,131-141$. 
Davis, F. D. (1989). Perceived Usefulness, Perceived Ease of Use, and User Acceptance of Information Technology. MIS Quarterly, 13, 319-340. https://doi.org/10.2307/249008

Davis, F. D. (1993). User Acceptance of Information Technology: System Characteristics, User Perceptions and Behavioral Impacts. International Journal of Man-Machine Studies, 38, 475-487. http://hdl.handle.net/2027.42/30954

https://doi.org/10.1006/imms.1993.1022

Davis, F.D. (1986). A Technology Acceptance Model for Empirically Testing New End-User Information Systems: Theory and Results. Cambridge, MA: Sloan School of Management, Massachusetts Institute of Technology.

Dias, J. (2002). Cell Phones in the Classroom: Boon or Bane? C@lling Japan, 10, 16-21.

Fishbein, M., \& Ajzen, I. (1975). Belief, Attitude, Intention, and Behavior: An Introduction to Theory and Research. Reading, MA: Addison-Wesley.

Hussin, S., Manap, M. R., Amir, Z., \& Krish, P. (2012). Mobile Learning Readiness among Malaysian Students at Higher Learning Institutes. Asian Social Science, 8, 276-283. https://doi.org/10.5539/ass.v8n12p276

Itayem, G. (2014). Using the iPad in Language Learning Courses: Perceptions of College Students (p. 1691). Theses and Dissertations, Toledo, OH: The University of Toledo. http://utdr.utoledo.edu/cgi/viewcontent.cgi?article=2714\&context=theses-dissertations

Koole, M. (2009). A Model for Framing Mobile Learning. In M. Ally (Ed.), Mobile Learning: Transforming the Delivery of Education \& Training (pp. 25-47). Athabasca: AU Press.

Kukulska-Hulme, A. (2013). Re-Skilling Language Learners for a Mobile World. Monterey, CA: The International Research Foundation for English Language Education. https://www.tirfonline.org/english-in-the-workforce/mobile-assisted-language-learnin g/

Kukulska-Hulme, A., \& Shield, L. (2007). An Overview of Mobile Assisted Language Learning: Can Mobile Devices Support Collaborative Practice in Speaking and Listening? Paper Presented at the EUROCALL 2007 Virtual Strand. http://vsportal2007.googlepages.com/Kukulska_Hulme_and_Shield_2007.pdf

Kukulska-Hulme, A., \& Shield, L. (2008). An Overview of Mobile Assisted Language Learning: From Content Delivery to Supported Collaboration and Interaction. ReCALL, 20, 271-289. https://doi.org/10.1017/S0958344008000335

Lavrakas, P. J. (2008). Encyclopedia of Survey Research Methods. Thousand Oaks, CA: SAGE Publications Ltd. https://doi.org/10.4135/9781412963947

Lawrence, B. (2015). Learner Receptiveness towards Mobile Technology in a College English Program: The Smart Decision? English Teaching, 70, 3-28.

Levy, M., \& Kennedy, C. (2005). Learning Italian via Mobile SMS. In A. Kukulska-Hulme, \& J. Traxler (Eds.), Mobile Learning a Handbook for Educators and Trainers (pp. 76-83). London: Routledge.

Pęcherzewska, A., \& Knot, S. (2007). Review of Existing EU Projects Dedicated to Dyslexia, Gaming in Education and M-Learning. WR08 Report to CallDysc Project. http://www.docstoc.com/docs/40115316/WR08-Existing-EU-Projects-review

Pollara, P. (2011). Mobile Learning in Higher Education: A Glimps and Comparision of Student and Faculty Readiness, Attitudes and Perception. Unpublished Doctoral Dissertation. https://digitalcommons.lsu.edu/gradschool_dissertations/234/

Prensky, M. (2005). What Can You Learn from a Cell Phone? Almost Anything! Innovate: Journal of Online Education, 1, No. 2

http://nsuworks.nova.edu/innovate/vol1/iss5/2 
Shield, L., \& Kukulska-Hulme, A. (eds.) (2008). Special Edition of ReCALL on Mobile Assisted Language Learning.

https://www.researchgate.net/publication/42798151_Special_issue_of_ReCALL_on_M obile_Assisted_Language_Learning

Steel, C. H. (2012). Fitting Learning into Life: Language Students' Perspectives on the Benefits of Using Mobile Apps. In M. Brown, M. Hartnett, \& T. Stewart (Eds.), Future Challenges, Sustainable Future, Proceedings of Ascilite Conference Wellington 2012 (pp. 875-880).

Stockwell, G. (2008). Investigating Learner Preparedness for and Usage Patterns of Mobile Learning. ReCALL, 20, 253-270. https://doi.org/10.1017/S0958344008000232

Surina, N., \& Kamaruzaman, J. (2009). A Study of Subject-Verb Agreement: From Novice Writers to Expert Writers. International Education, 2, 190-194.

Tayebinik, M., \& Puteh, M. (2012). Mobile Learning to Support Teaching English as a Second Language. Journal of Education and Practice, 3, 56-62.

Traxler, J. (2009). Learning in a Mobile Age. International Journal of Mobile and Blended Learning, 1, 1-12. https://doi.org/10.4018/jmbl.2009010101

Zhu, Q., Guo, W., \& Hu, Y. (2012). Mobile Learning in Higher Education: Students' Acceptance of Mobile Learning in Three Top Chinese Universities. Unpuplished Bachelor's Thesis. http://www.diva-portal.org/smash/get/diva2:536882/FULLTEXT01.pdf 